\title{
TV/Series
}

$4 \mid 2013$

Écho et reprise dans les séries télévisées (II) : Re-

présentations -- enjeux socio-culturels, politiques et

idéologiques de la reprise

\section{Rich Dykes from L.A. are called Lesbians}

\section{Anne Crémieux}

\section{OpenEdition}

\section{Journals}

Electronic version

URL: http://journals.openedition.org/tvseries/738

DOI: $10.4000 /$ tvseries.738

ISSN: 2266-0909

\section{Publisher}

GRIC - Groupe de recherche Identités et Cultures

\section{Electronic reference}

Anne Crémieux, «Rich Dykes from L.A. are called Lesbians », TV/Series [Online], 4 | 2013, Online since 15 December 2013, connection on 19 April 2019. URL : http://journals.openedition.org/tvseries/738 DOI : $10.4000 /$ tvseries.738

\section{(c) (i) (3)}

TV/Series est mis à disposition selon les termes de la licence Creative Commons Attribution - Pas d'Utilisation Commerciale - Pas de Modification 4.0 International. 
Rich Dykes from L.A. are called Lesbians

Anne CRÉMIEUX

"Have you ever thought about suing The L Word crew for stealing so many of your ideas?" writes DeLandDeLakes on the blog of Alison Bechdel, the creator of Dykes to Watch Out For. Another blogger described DTWOF as "The L Word, in comic strip form, before The L Word ever existed." I would like to present how The $L$ Word does indeed share quite a few traits with $D T W O F$. Indeed, both series portray a group of lesbian friends who live the lesbian life, speak about and experience such community events as gay pride or lesbian cruises, have babies through artificial insemination, and famously set up charts to keep track of reported sexual encounters. In both cases, the serial form allows for strong identification with diverse characters, who present conflicting takes on gender and sexuality, personal and political ethics. One major element, however, is the difference in medium and audience range. As a comic strip published exclusively in underground, queer magazines, Bechdel's series never reached the mainstream audience The $L$ Word had to seduce to survive its first season on Showtime. The two series offer different approaches to American late 20th c. / early 21st c. lesbian culture, showing how targeting a much broader TV audience might have resulted in a slightly different depiction of how women navigate their gender and sexuality to self-identify as lesbians, rather than dykes.

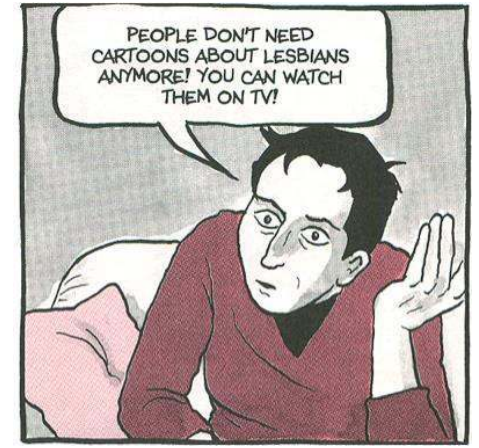

Plate 1 in Are You My Mother (Allison Bechdel, 2011, p.·70)

$\mathrm{T}$

The Dykes to Watch Out For (referred to as DTWOF) were published from 1983 to 2008 in up to fifty lesbian, gay, and feminist alternative newspapers. By 2008, lesbian visibility was becoming almost banal on TV and popular culture in general, with Madonna kissing Britney Spears and Christina Aguilera at the 2003 MTV Video Music Awards, and The L Word in its fifth of six seasons. Officially, Alison Bechdel stopped producing her weekly comic-strip lesbian soap opera because of the immense success of Fun Home (published in 2006), and a contract to complete a second graphic memoir that became Are You My Mother? That same year, a Dyke anthology came out for people who wanted to catch up quickly on the comic strip by the author of Fun Home (see Plate-2). 


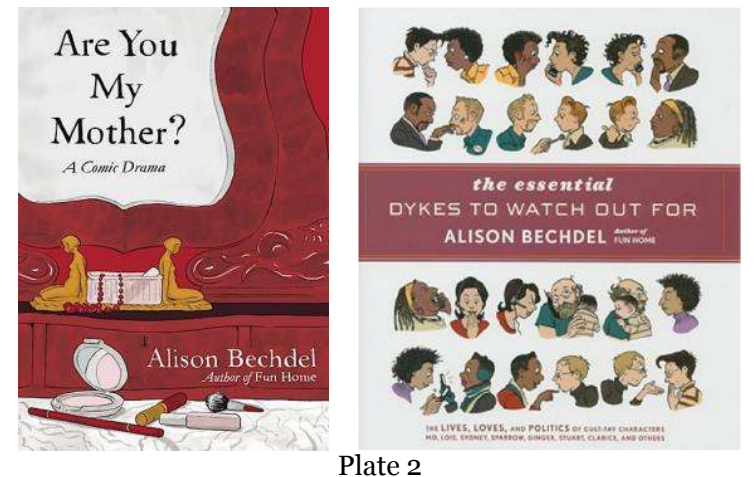

The $L$ Word (see Plate 3) ran on Showtime from 2004 to 2009, in the footsteps of the American remake of Queer as Folk, that ran on the same network from 2000 to 2005. It was created by Ilene Chaiken, who first pitched her idea to Showtime in 2000, so that while The DTWOF preceded the lesbian TV show by two decades, they did overlap.

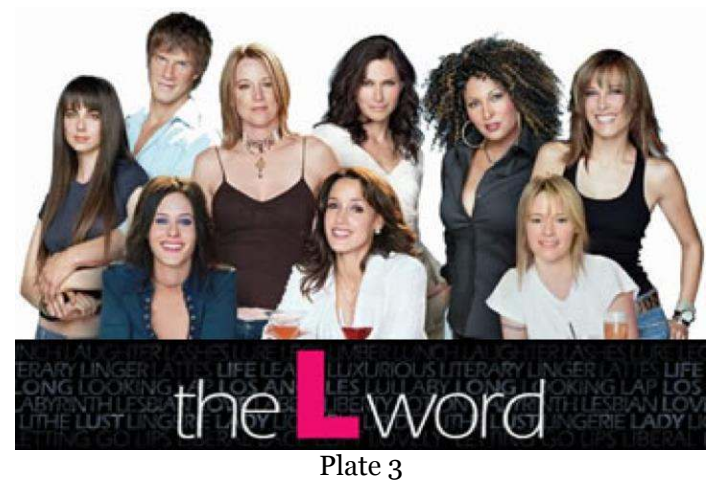

In both The $L$ Word and DTWOF, the serial form allows for strong identification with diverse characters, who present conflicting takes on gender and sexuality, personal and political ethics. But before looking at the strong connections between The L Word and the DTWOF in terms of plot, characterization, and representation of lesbian culture and sexuality, it must be pointed out that the DTWOF largely parodied the film franchise and TV series form, and constantly commented on the presence and significance of lesbian visibility in the mainstream media, which the comic strip was self-consciously not part of. 
Starting with the second DTWOF book, Alison Bechdel presented her work first as a mass-consumption commodity, then as a mainstream popular series, spoofing marketing campaigns known to all (see Plate 4 and Plate 5).

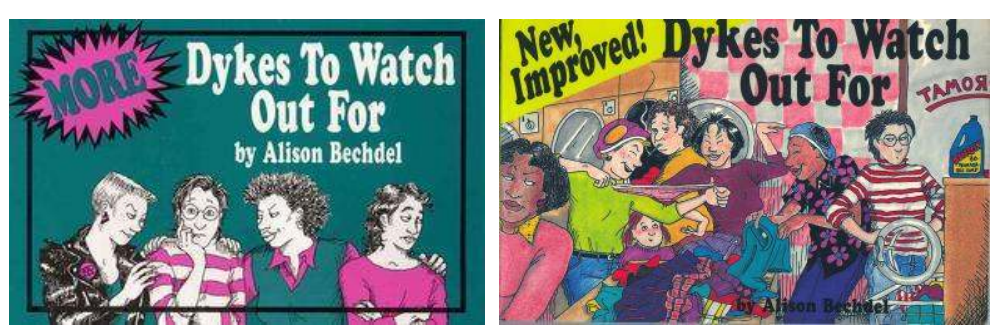

Plate 4: Volumes 2 and 3 - playing on common mass marketing techniques, applied to an underground publication.

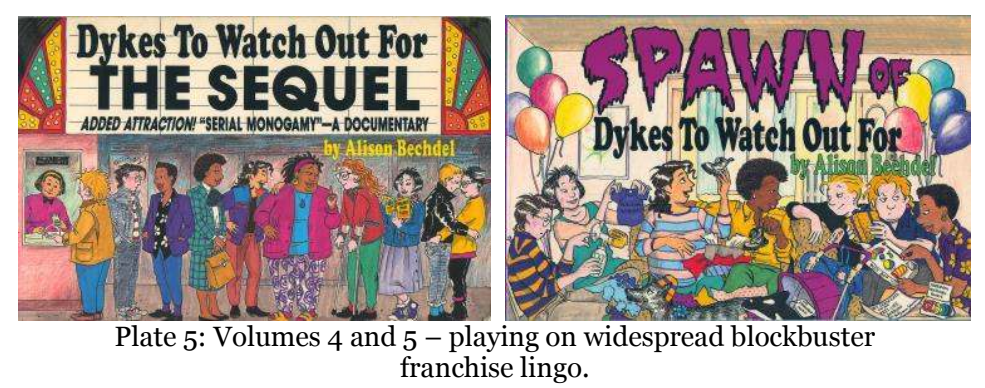


The entertainment industry is further spoofed in added opening sequences in the form of highly referential ("It's a nerd! It's a Pain! It's Mo!"), overly verbose and alliteration-prone credits (see Plate 6 and Plate 7).
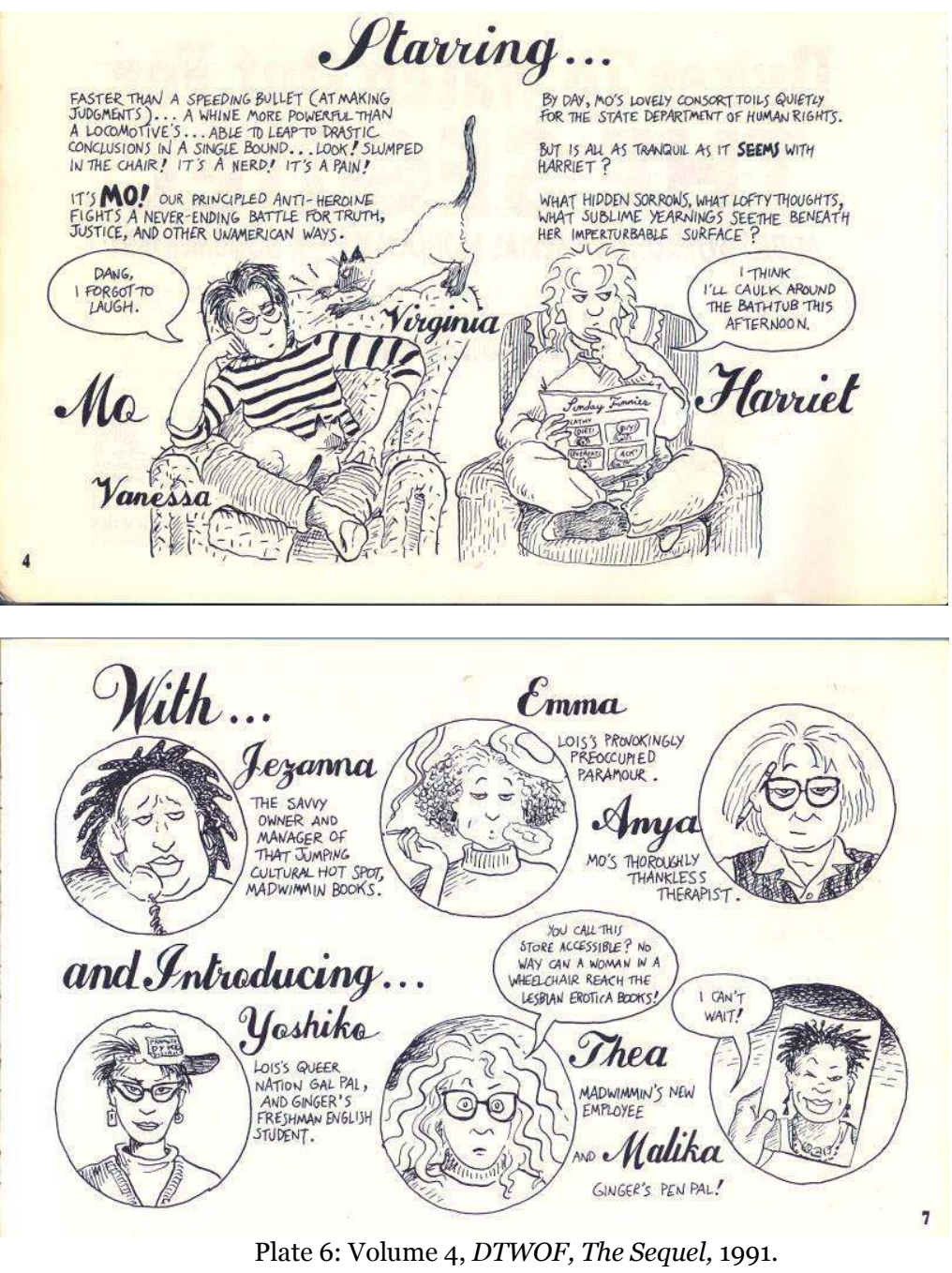
Featuring .... our stalwart cultural workers...

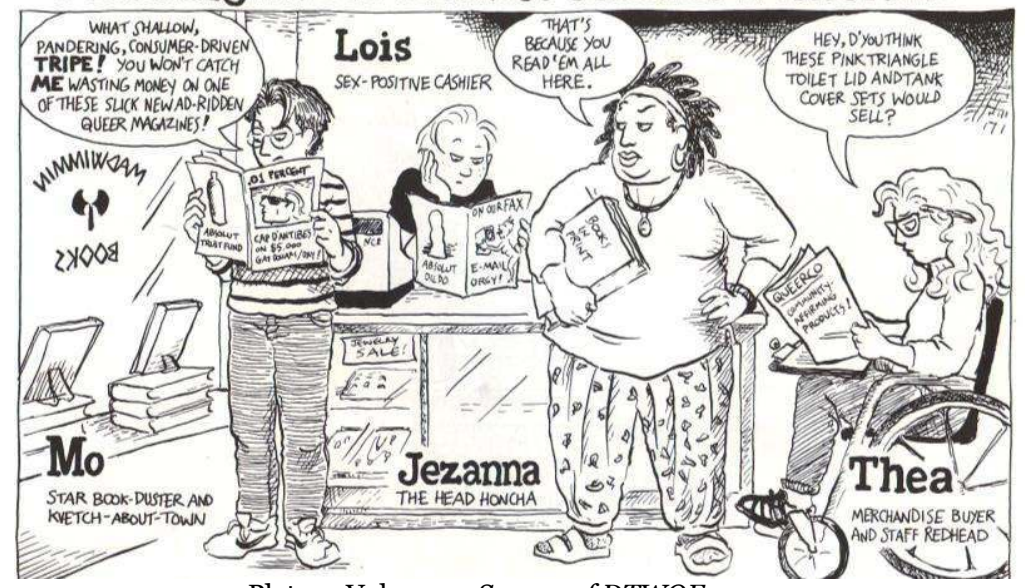

Plate 7: Volume 5, Spawn of DTWOF, 1993.

Volume 9 adopts the TV series format with a "previously on" introductory section that underlines the commercial strategy of the cliffhanger, by urging potential readers to actually buy the book (see Plate 8).
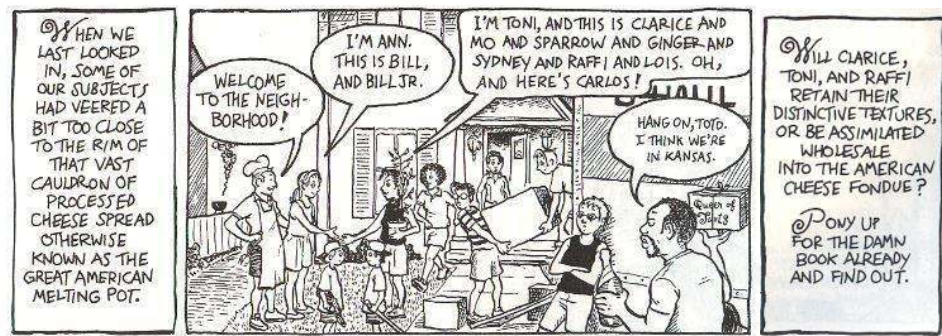

Plate 8: "Previously on" section in vol. 9, Post-DTWOF, 1999; also used in vol. 10, Dykes and Sundry Other Carbon-Based Life Forms TWOF, 2001. 
The similarities between the two series are striking, as many have noticed. A post to be found on Alison Bechdel's blog candidly asks: "Have you ever thought about suing "The L Word" crew for stealing so many of your ideas 1 ?" No reply was posted. Another blogger described DTWOF as "The $L$ Word, in comic strip form, before The $L$ Word ever existed ${ }^{2}$."

The two series have a lot in common, in spite of a somewhat different approach, which can easily be spotted in the following parallels. Both portray a group of lesbian friends who live the lesbian life. They famously set up charts to keep track of reported sexual encounters in The $L$ Word (see Plate 9), and of more diverse relationships in DTWOF (see Plate 10).
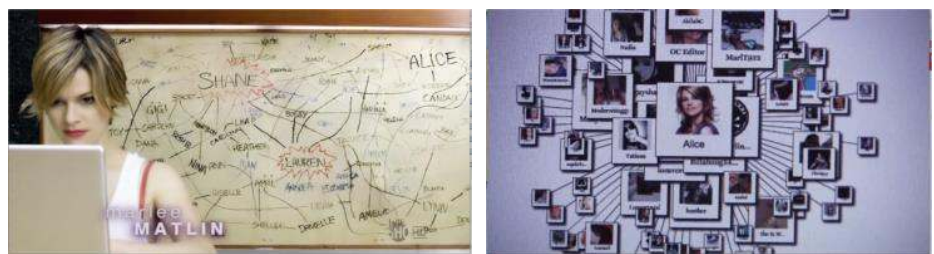

Plate 9: The Alice-centric universe, as presented in the series credit sequence (left, 2004), and the computer version in 5.8 (right, 2008).

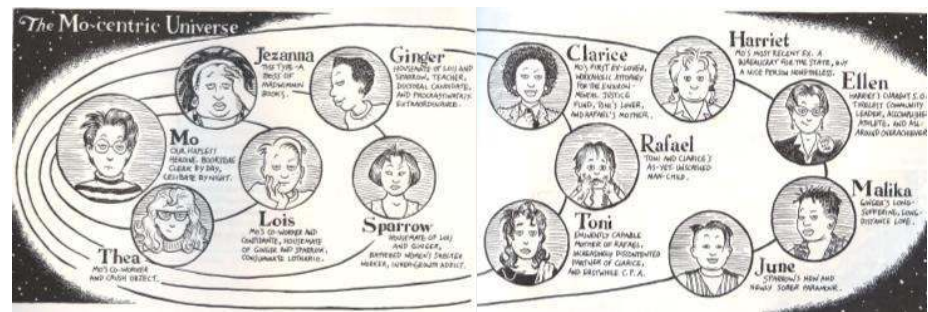

Plate 10: Mo's Chart, vol. 6, Unnatural DTWOF, 1995, Introduction.

${ }^{1} \mathrm{http}$ ///dykestowatchoutfor.com/give-the-people-what-they-want, posted April 25, 2007 at 9:51 pm, last accessed Sept. 15, 2012.

2 http://whatmarkread.blogspot.com/2011/04/fun-home-by-alison-bechdel.html, , posted Tuesday, April 26, 2011, last accessed Sept. 15, 2012. 
In both series, one central couple has a baby through artificial insemination. The $L$ Word introduces Bette and Tina as future parents in the pilot, while DTWOF follows Clarice and Tina's conception and parenting of their son (Plates 11 and 12)

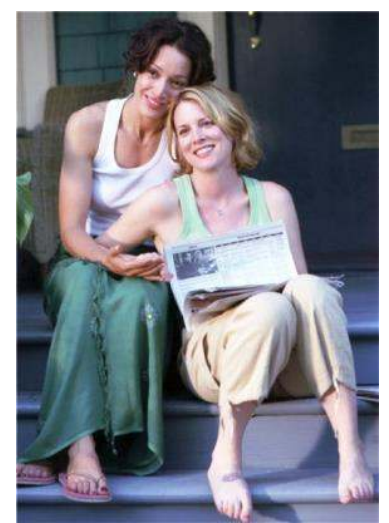

Plate 11: Bette and Tina on their stoop $(1.1,2004)$.

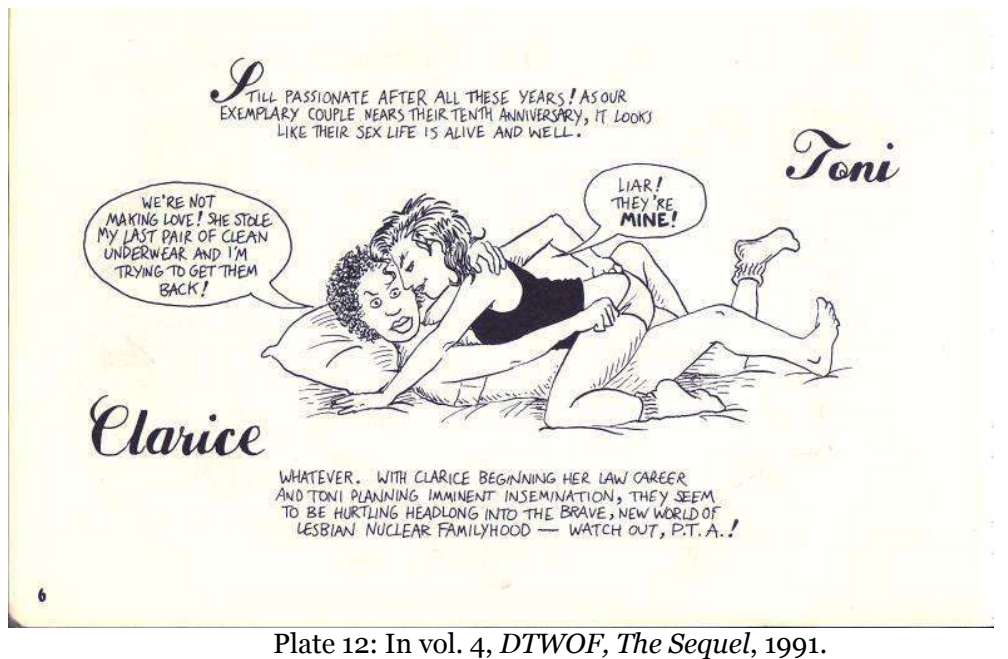

The Tina/Bette relationship (Plate 11) is strangely similar to the Toni/Clarice relationship (Plate 12), with both Bette and Clarice being black (Bette is actually bi-racial) and cheating on their girlfriends with a black woman, working too much, being the provider and less involved parent, to ultimately break up, with much suffering going on. 
The main characters speak about and experience such community events as gay pride - and specifically join the dykes on bikes (see for example vol. 6, Unnatural DTWOF, 1994, strip 192, and episode 2.11, 2005). The main $L$ Word characters are invited on the lesbian Olivia cruise in season 2 (2005) while the $D T W O F^{\circ}$ s main character, Mo, is sarcastically portrayed as wanting to go when in the depth of depression (plate 13).
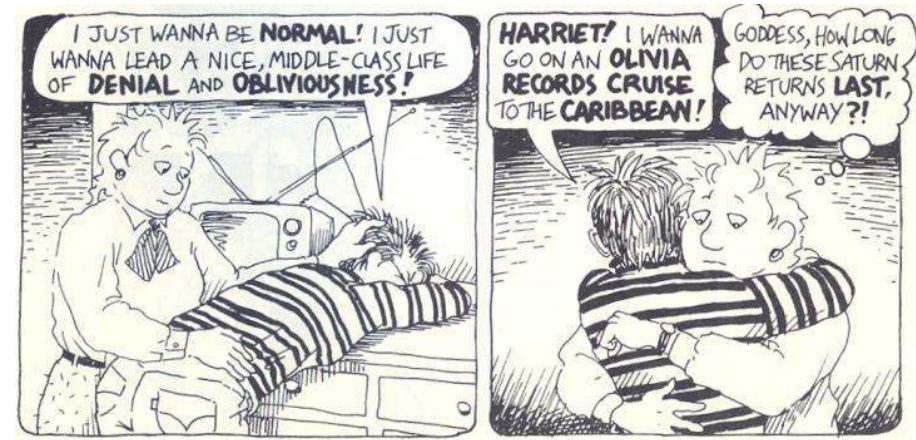

Plate 13: Mo is having one of her famous meltdowns

95

(vol. 3, New, Improved DTWOF, 1989, strip 66).

Both series include quite a bit of queer, gender-bending, nonconformist, unexpected sex, with some rather interesting similarities (see Plate 14 and Plate 15).

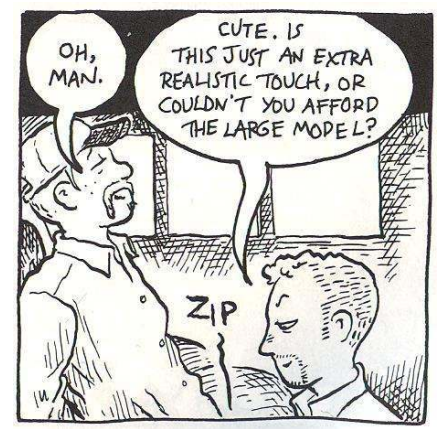

Plate 14: Lois, drag-kinging as Max, has oral sex with transsexual Jerry (vol. 9, Post-DTWOF, 2000, "In flow state" section, p. 121). 


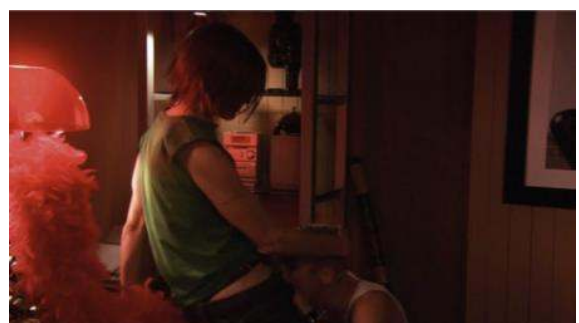

Plate 15: Transgender Max has oral sex with gay Billie (3.06, 2006).

In both instances, a gay man is giving a blow-job to a heretofore straight transgender man wearing a dildo, with Lois being a drag-king performer and Max a pre-op transsexual. In fact, Jerry is also a transsexual man who happens to be gay, and who caught Lois' eye a while back. As with Toni and Tina's names, the onomastic connections are remarkable.

While this episode of The $L$ Word was often cited as particularly daring, it can be argued that the DTWOF had gone further, sooner, and had included a much wider variety of trans characters, from Asian vegan drag-kinging farmer ex-girlfriend Milkweed dropping in on Sparrow, to African American trans teenager Jonas/Janis struggling with her mother to access hormones.

Bi-sexuality is also explored by both series, with similar conundrums, such as being judged by one's lesbian friends when trying a male lover, or that male lover identifying as a lesbian and calling herself Lisa. When self-identified "bi-dyke" Sparrow from the DTWOF has sex with the repeatedly lesbian enamored Stuart, she wishes for "something more missionary" (see Plate 16), in the same way as The $L$ Word Alice grows weary of her lesbian-identified boyfriend Lisa's refusal to use "the real thing" $(1.8,2005$, see Plate 17). 


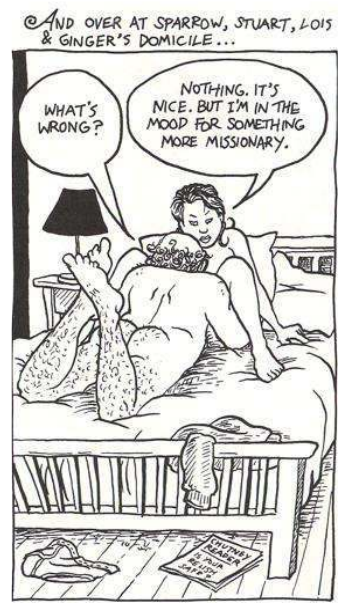

Plate 16: In vol. 9, Post-DTWOF, 2000, "In flow state" section, p. 95.

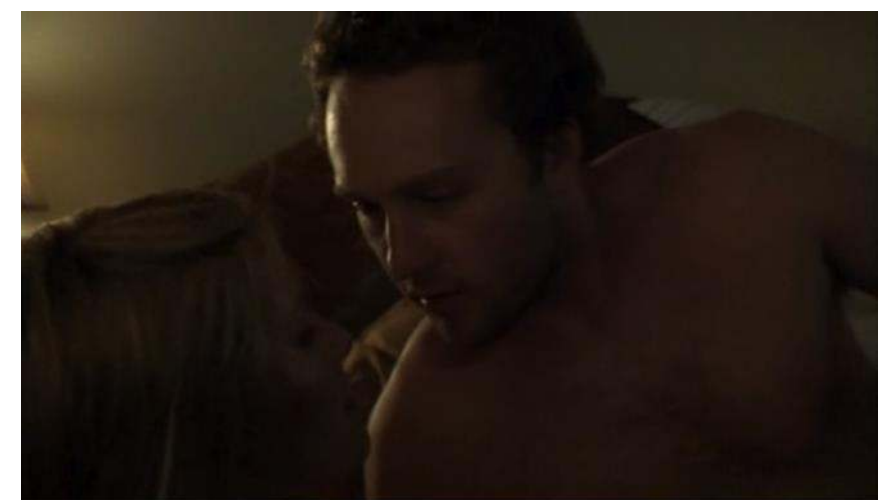

Plate 17: Lisa pulls out a dildo to make love to Alice, who is none too pleased: "ALICE. But you're a man / LISA. I'm a lesbian man." (1.8, 2005).

In both series, a condom is used during sex with a dildo (again involving Max in The L Word and Lois in DTWOF), and Alison Bechdel explains how it can be "purely conceptual, for an extra little thrill of verisimilitude" (see Plate 18). 


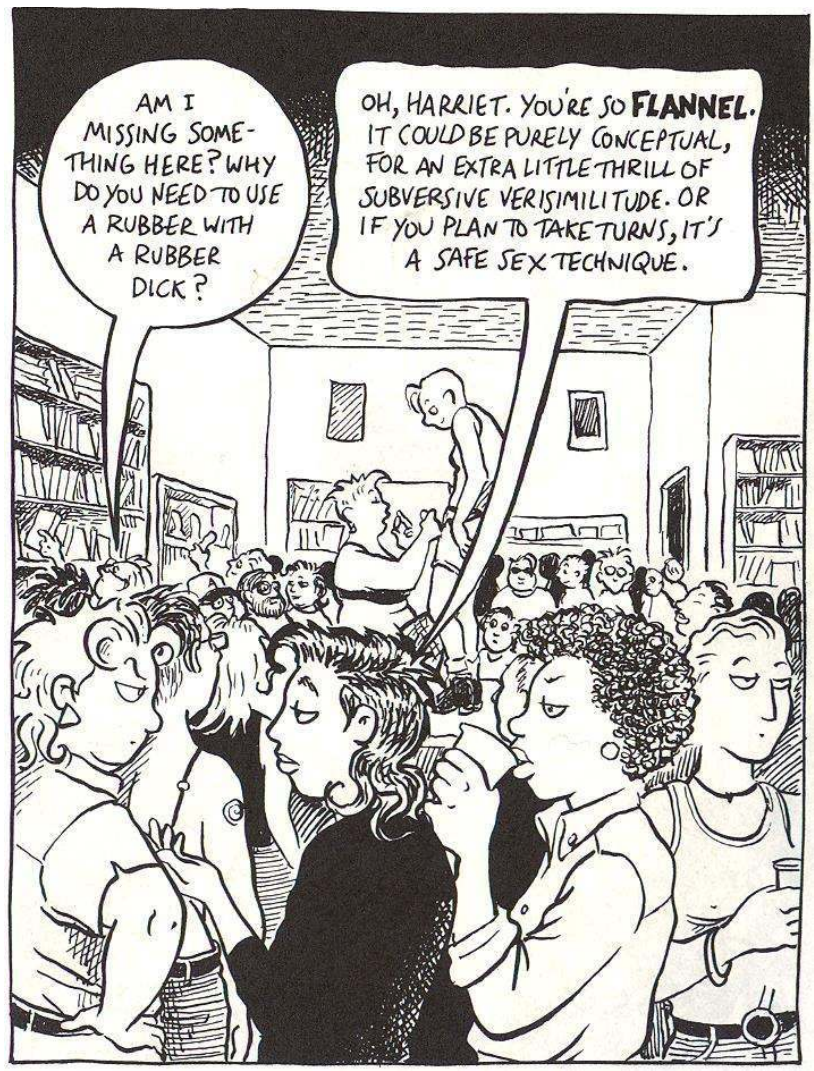

Plate 18: In vol. 7, Hot, Throbbing DTWOF, 1998, "Sense \& Sensibility" section. 
One of the most strikingly similar scenes of queer sexuality exposed may be the boarding of planes with dildos in luggage, with the same configuration of the shyer character (Mo/Dana) hiding behind her hand while the more blasé (Sidney/Alice) cracks a joke in self-defense (see Plate 19 and Plate 20).
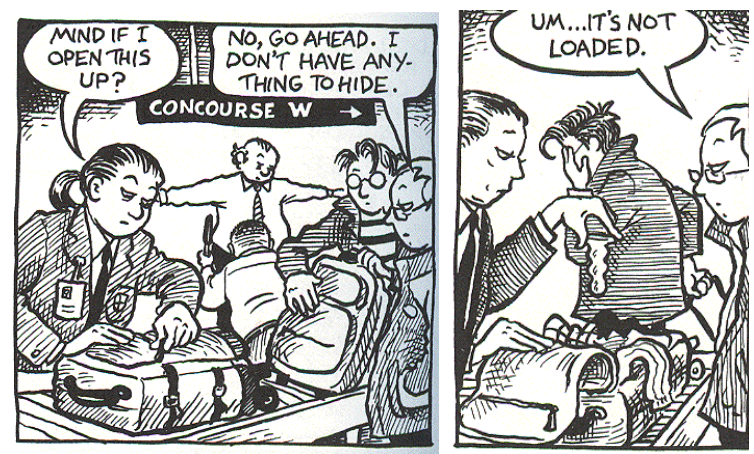

Plate 19: In vol. 10, Dykes and Sundry Other Carbon-Based Life Forms TWOF, 2001.
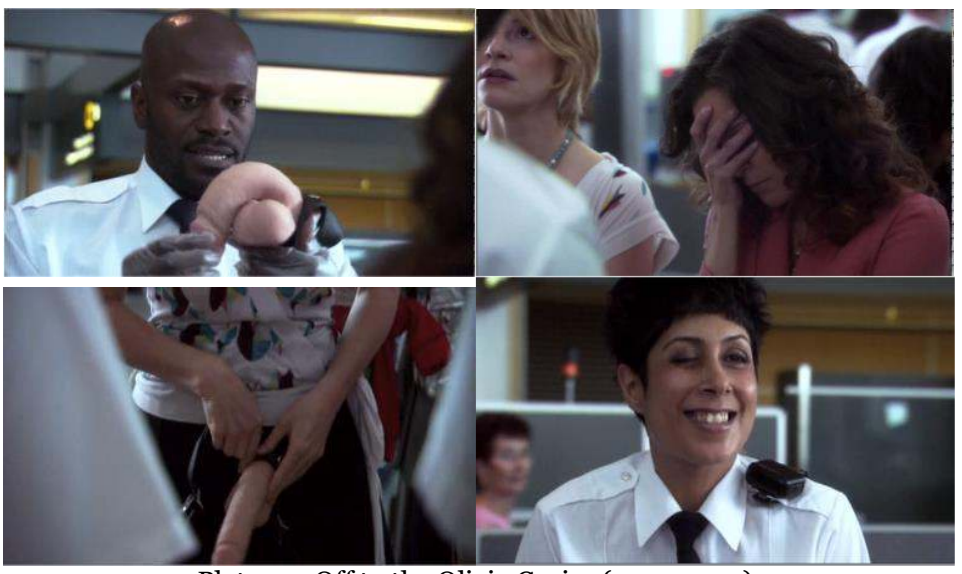

Plate 20: Off to the Olivia Cruise $(2.10,2005)$. 
The same two couples are the ones shown to most enjoy roleplaying (see Plate 21 and Plate 22).

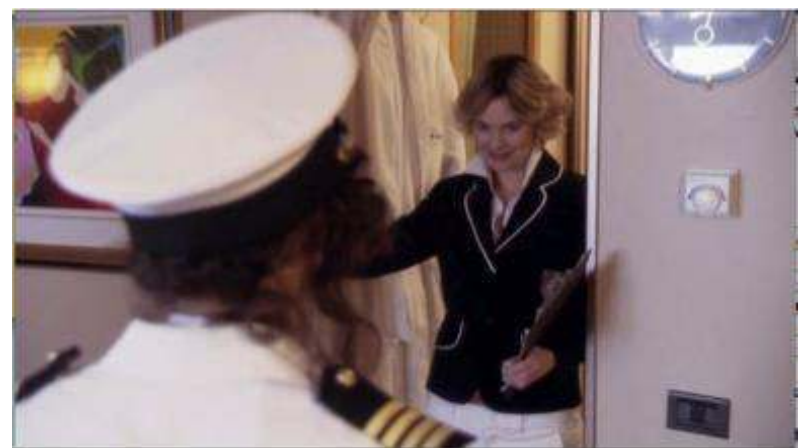

Plate 21: Alice and Dana on the Olivia Cruise, playing July McCoy and Captain Stubing (hence the dildo) from the TV series The Love Boat $3(2.10,2005)$.

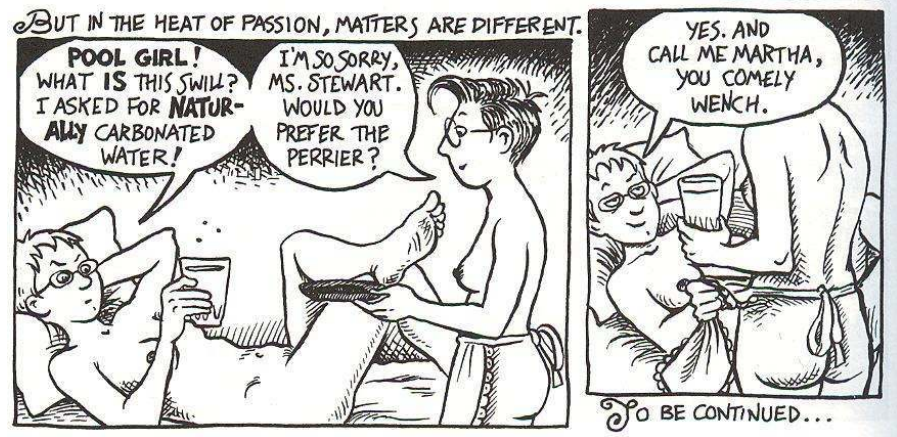

Plate 22: Mo and Sidney play Martha Stewart and the pool girl, dildo-less (vol. 7, Hot, Throbbing DTWOF, 1998, strip 290).

Again, it may be pointed out that all instances of role playing in the DTWOF involve two female roles (Millionaire business woman and TV show host Martha Stewart is a recurring one), while they are always a reproduction of a straight situation in The $L$ Word, in accordance with a very butch/fem, top/bottom sex role attribution that is largely absent from the DTWOF.

${ }^{3} \mathrm{ABC}, 1977-1986$. 
On the dramatic side, both series show women experiencing breast cancer and losing a parent (see Plate 23 and Plate 24).

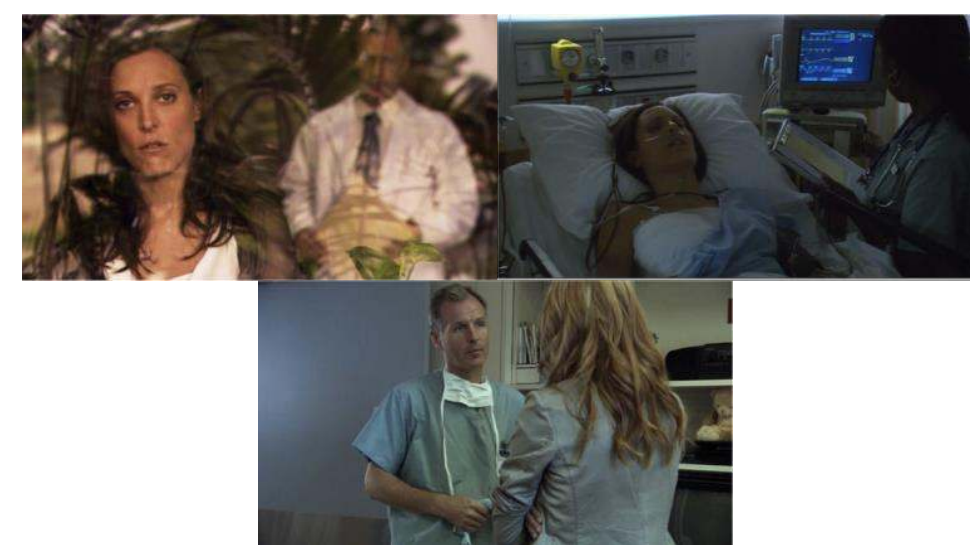

Plate 23: Dana has cancer, season 3, 2006. Screenshot 1: "We are going to take good care of you" (3.05); Screenshot 2 and 3: "We only release medical information to the immediate family" (3.06).

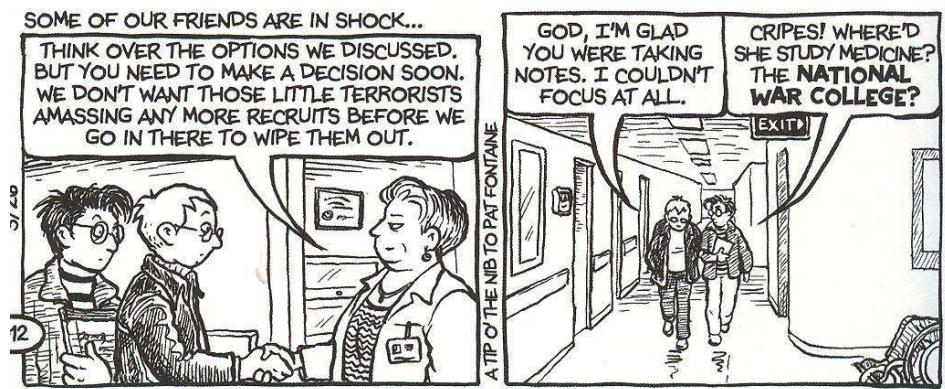

Plate 24: Sidney has cancer (vol. 11, Invasion of the DTWOF, 2003, strip 412).

While cancer in the DTWOF triggers Mo's ever present political consciousness, as she disapproves of the war on terror pervading every aspect of American life in 2003, The $L$ Word denounces the lack of protection of same-sex couples experiencing medical drama and death. Both series adopt a political approach, but from a different perspective. The $L$ Word focuses on gay and lesbian rights, while the DTWOF comment on American politics in general (see Plate 25 and Plate 26). 


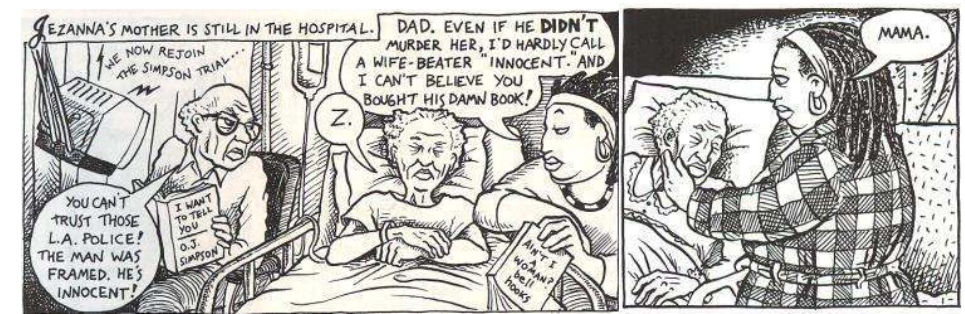

Plate 25: Jezanna discusses the O.J. Simpson case with her father at her mother's bedside (vol. 6, Unnatural DTWOF, 1995, strip 208). Jezanna's mother dies in vol. 7, Hot, Throbbing DTWOF, 1998, strip 279.

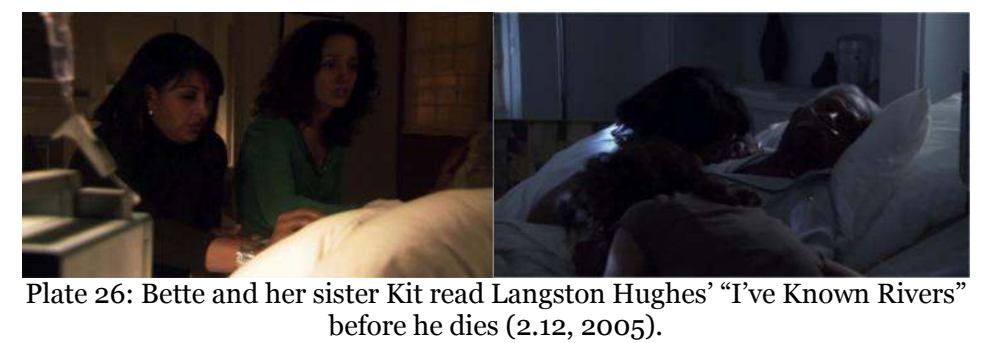

While both series include African American cultural specificities, the DTWOF refers to a contemporary political event that divides the family (note the books read by father and daughter), while The $L$ Word quotes the Harlem Renaissance African American poet the father loved.

As noted with the blog entries earlier, these similarities have been pointed out by others. A yet to be published paper was given by Bo Owens (U. of Utah) at the International Society for Cultural History and Cultural Studies annual Humanities Conference in Mexico City in November 2011: entitled "Failed Men and Perfect Women: Masculinity, Race, and Intimacy in Fictional Lesbian Narratives," it deals with how The $L$ Word and the DTWOF, in spite of their "remarkably similar story arcs" and the issues they address (bisexuality, breast cancer, transmasculinity, non-monogamy, adoption...), result in very different representations of female masculinity, race, and sexuality, due to the creators' "ideologies and personal experiences, as well as the differing standards of their respective mediums."

Indeed, Alison Bechdel has shown with her Firebrand book covers and introductory sections that she was aware of the difference in medium and reach even before gay- and lesbian-oriented TV series became available on prime-time television. Compared to a major cable network, an alternative comic strips, and the audience range each medium implies, allowed Bechdel a freedom mainstream entertainment 
artists may not have.

Firebrand Books is an award-winning feminist and lesbian publishing house. We are committed to producing quality work in a wide variety of genres by ethnically and racially diverse authors. Now in our four. teenth year, we have over ninety titles in print.

A free catalog is available on request from Firebrand Books, 141 The Commons, Ithaca, New York 14850, 607-272-0000.

Visit our website at www.firebrandbooks.com.

Plate 27

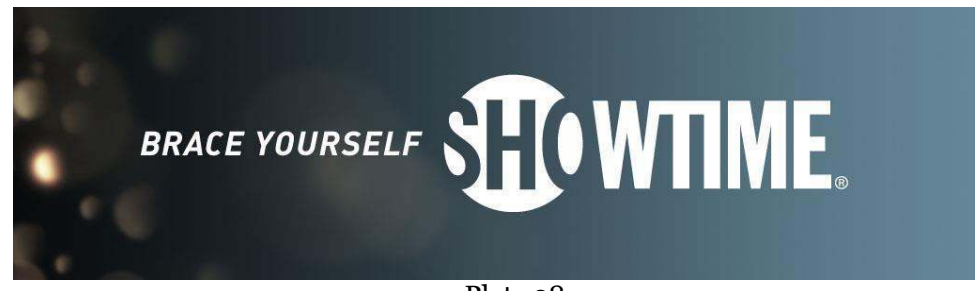

Plate 28

As a comic strip published exclusively in underground, queer magazines and edited by Firebrand (see Plate 27), Bechdel's series never reached the mainstream audience The $L$ Word had to seduce to survive its first season on Showtime (see Plate 28), so that the DTWOF could remain rather high-brow, spoofing academic writings while explaining complex theories (see Plate 29). 


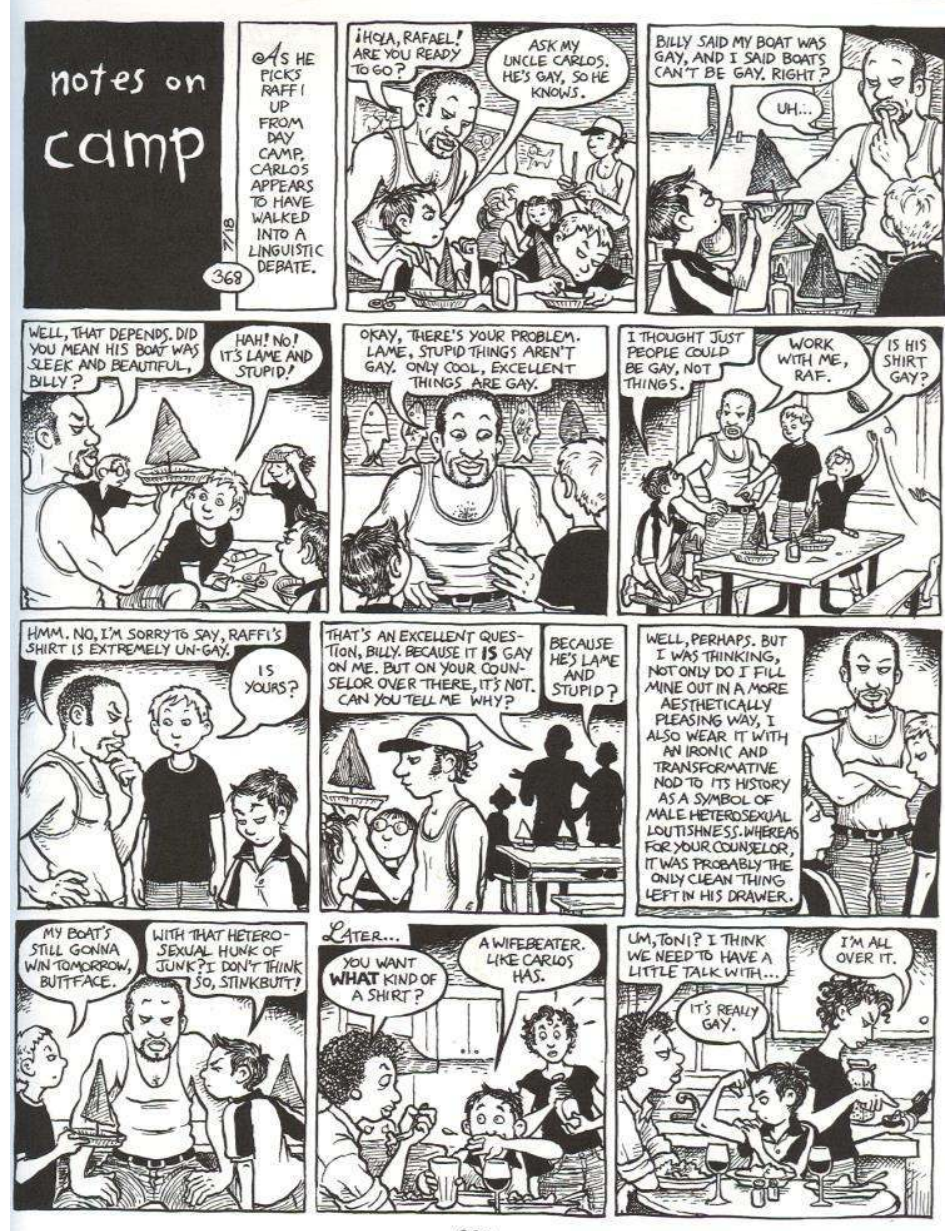

263

Plate 29: As Carlos explains how only "cool, excellent things are gay," Billy and Raffi question whether such things as a shirt, as opposed to people, can be gay. The title, "Notes on Camp", is a reference to Susan Sontag's 1964 essay on camp as an aesthetic phenomenon.

(vol. 10, Dykes and Sundry Other Carbon-Based Life Forms TWOF, 2001, strip 368). 
Although I happen to have heard Alison Bechdel say she did not watch The $L$ Word 4 , for fear it would change the way she created the DTWOF, she is aware of the existence and impact of the show, as the title image implied (see Plate 1 above). The DTWOF strips do refer to other lesbian-related shows, always with a certain amount of angst at the mounting lesbian visibility, as expressed by Bechdel's alter-ego, Mo (see Plate 30).

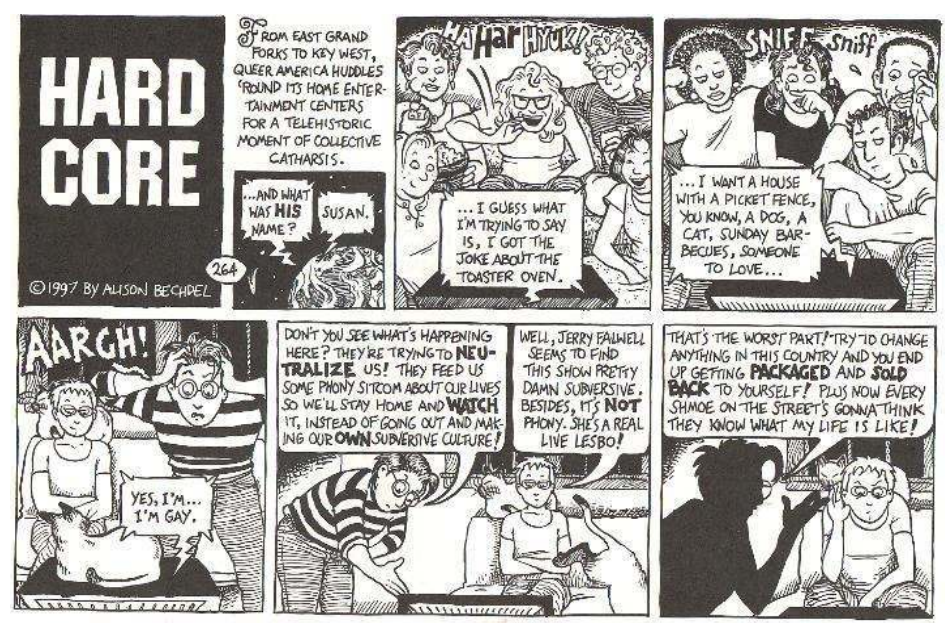

Plate 30: In vol. 7, Hot, Throbbing DTWOF, 1997, strip 264, referring to Ellen (ABC, 1994-98), 4.22 \& 23, "The Puppy" episode.

In this strip, the whole community is watching Ellen DeGeneres come out. Frame 2 brings together lesbian fems and butches, radicals and less radical, while frame 3 has the two Latinos cry in the arms of their same-sex lovers. While Sidney remarks that conservative forces such as televangelist Jerry Falwell have responded rather violently, Mo is appalled at how smooth Ellen's coming out to her friends is, and worries about her subversive lesbian culture disappearing and her lifestyle becoming familiar to the mainstream, with the pressure to conform that will inevitably follow. And indeed, in the next panel, in which Mo is visibly turned on by Ellen's coming out, she is interrupted by a phone message from her mother calling to praise Ellen's coming out, suggest Mo should get the same haircut and possibly manage a store like the show's heroine, instead of simply working in one (see Plate 31).

${ }^{4}$ A. Bechdel presenting Fun Home at the Center for New Words, Simmons College, June $24^{\text {th }}, 2006$. 


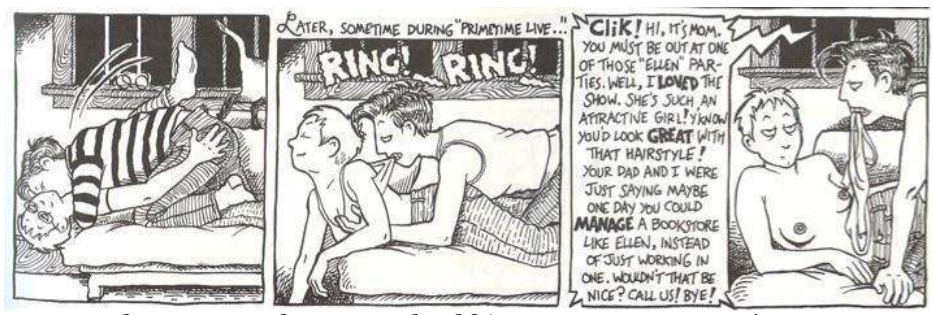

Plate 31: In vol. 7, Hot, Throbbing DTWOF, 1997, strip 264.

Another example of Bechdel characters in touch with lesbian visibility in popular culture is young Republican and aspiring CIA agent Cynthia. During her Arabic lesson, she explains that she watched the cult series Buffy, the Vampire Slayer (WB and UPN, 1997-2003), with her girlfriend (see Plate 32).

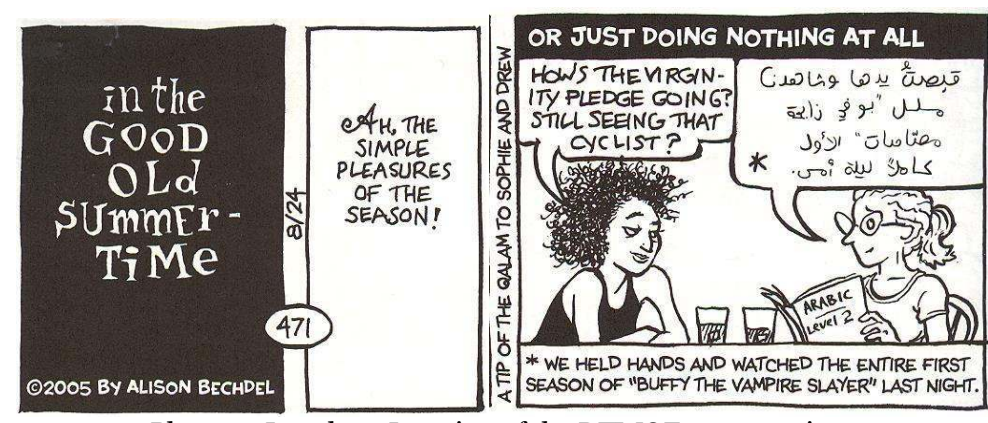

Plate 32: In vol. 11, Invasion of the DTWOF, 2005, strip 471.

Bechdel was aware of the importance of these "telehistoric moments" in mainstream shows such as Buffy, and their impact on the lesbian community, but also, early on, of the changing lesbian culture, as can be seen in this 1994 strip (Plate 33). 


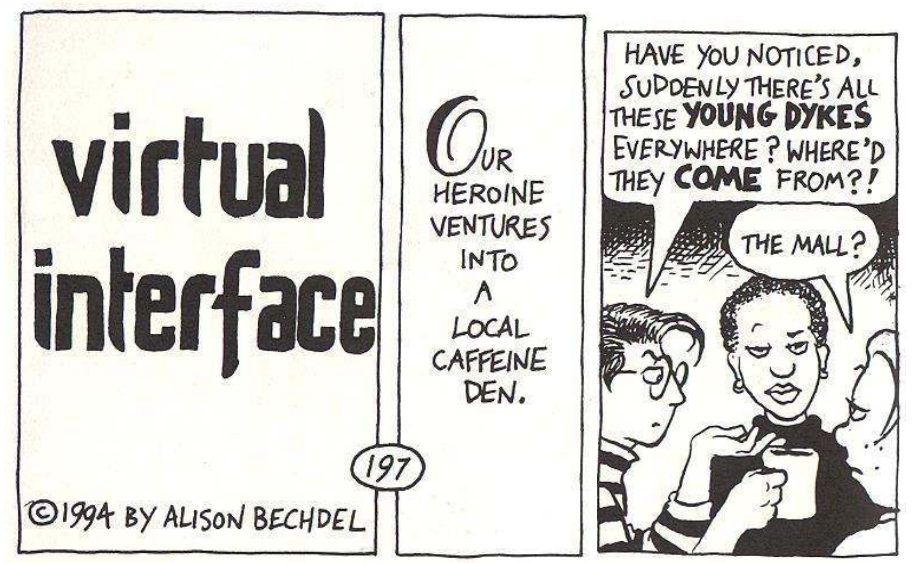

Plate 33: In vol. 6, Unnatural DTWOF, 1994, strip 197.

While Mo clearly makes the connection between lesbian visibility and the changing lesbian culture (Plate 30), and keeps deploring it, Bechdel humorously explains in her introduction to the Essential DTWOF (2008) that she has always wanted this visibility for lesbians (see Plate 34), imagining a world that would open up to the margins, rather than margins that would disappear into the mainstream as she did not foresee the effect a larger exposure, such as a lesbian TV series, would inevitably have (see Plate 35 ).

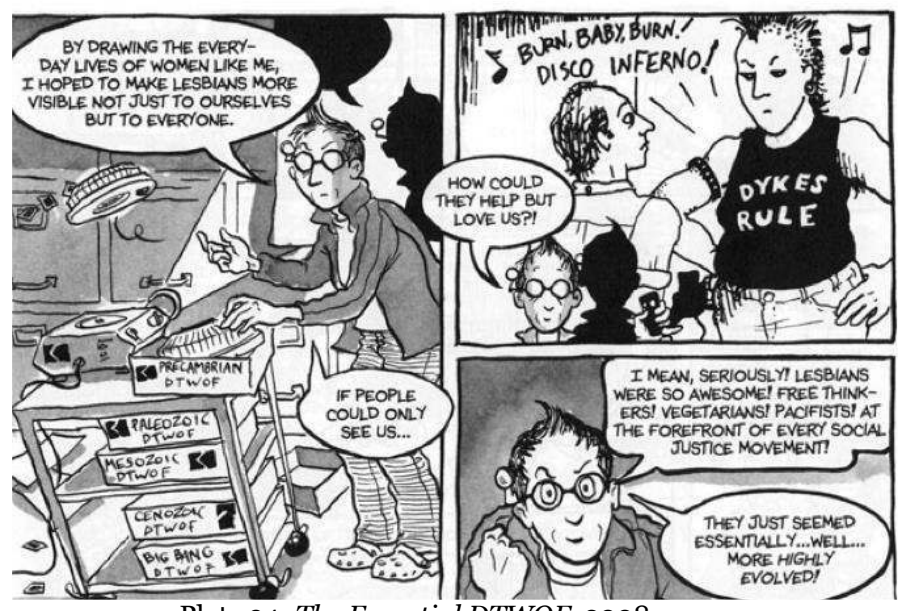

Plate 34: The Essential DTWOF, 2008, p. xv. 


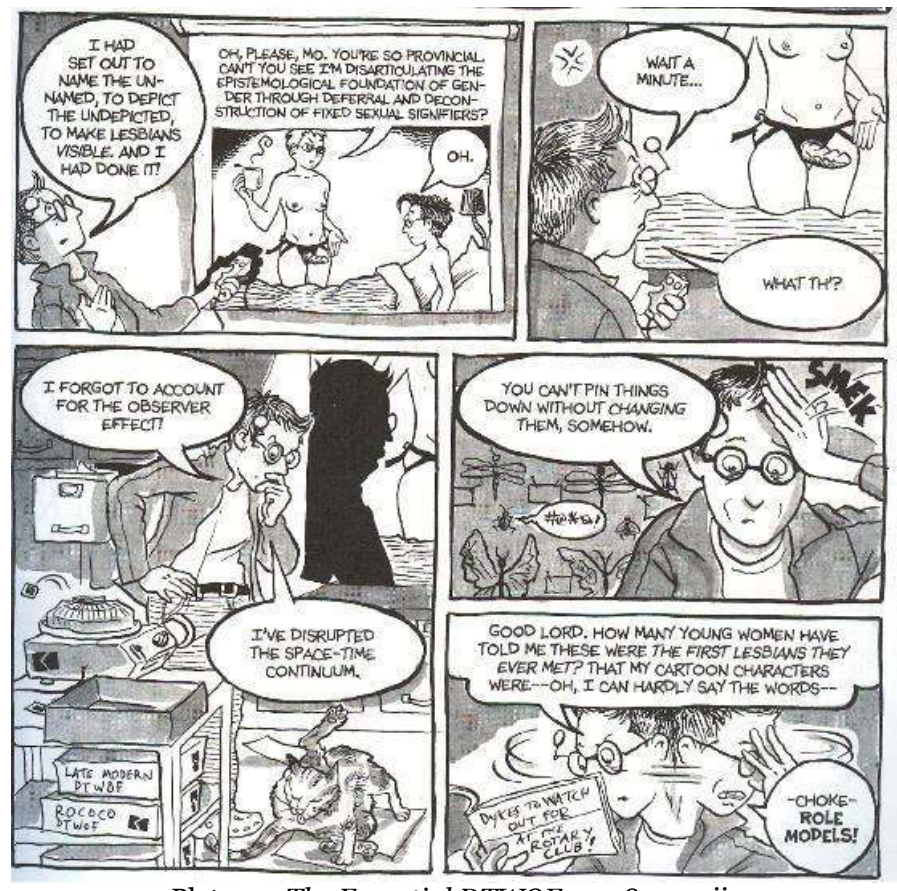

Plate 35: The Essential DTWOF, 2008, p. xvii.

In the introduction to her tenth volume and twentieth anniversary issue (2003), Bechdel already explained that she understood the evolution of her dyke turned lesbian culture only too well, and that her success is both a cause and an effect of this change:

As I watched our liberation movement flower into first a niche market, then a sitcom punchline, then a full-blown sitcom premise, before withering out of fashion like a pierced septum [...]I've reluctantly come to accept that the whole point of a liberation movement, after all, is to render itself obsolete, but I was resistant at first 5 .

Just as Bechdel cannot possibly be unaware of the impact of The $L$ Word whether she watches it or not, it is very unlikely that the makers of The $L$ Word would not know of the DTWOF'.

As the above examples have illustrated, the two series offer different approaches to American late $20^{\text {th }} \mathrm{c}$. and early $21^{\text {st }} \mathrm{c}$. lesbian

${ }^{5}$ Dykes and Sundry Other Carbon-Based Life Forms TWOF, 2001, p. 12.

${ }^{6}$ I found no reference to Alison Bechdel from The $L$ Word creators in interviews and official publications. 
culture, showing how targeting a much broader TV audience might have resulted in a significantly different depiction of how women navigate their gender and sexuality to self-identify as lesbians, rather than dykes, the difference being the level of political involvement and the embracing of gender bending. The $L$ Word lesbians follow the heterosexual canons of beauty while the Dykes counter-identify or, more to the point, disidentify with these canons of beauty. The political beliefs of The $L$ Word lesbians are limited to lesbian and gay rights, while the Dykes follow the political line that "none are free as long as one is oppressed."

One illustration of the more limited political scope of The $L$ Word compared to the DTWOF is seen when denouncing discrimination against lesbians and transmen. When Moira/Max applies for a job, she is rejected as Moira (3.5) and hired as Max (3.10), for a higher pay, unrecognized by the man who passed him over as Moira (see Plate 36 and Plate 37).

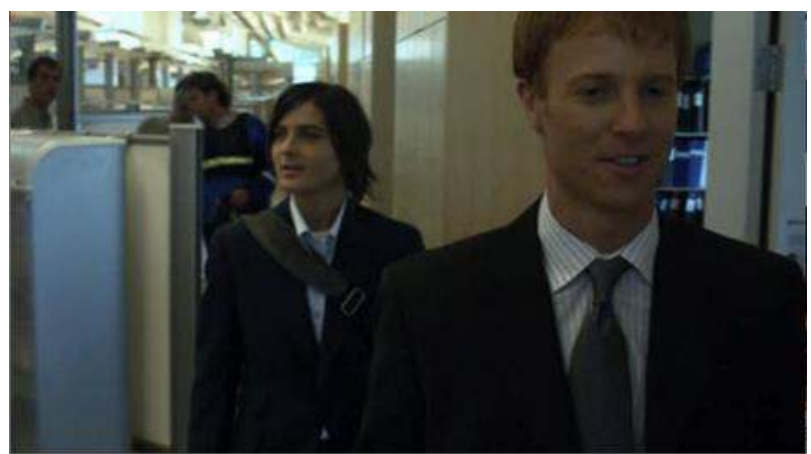

Plate 36: "MAN. Moira, that's a girl's name isn't it? MOIRA. Yeah, I'm a girl.” (3.5)

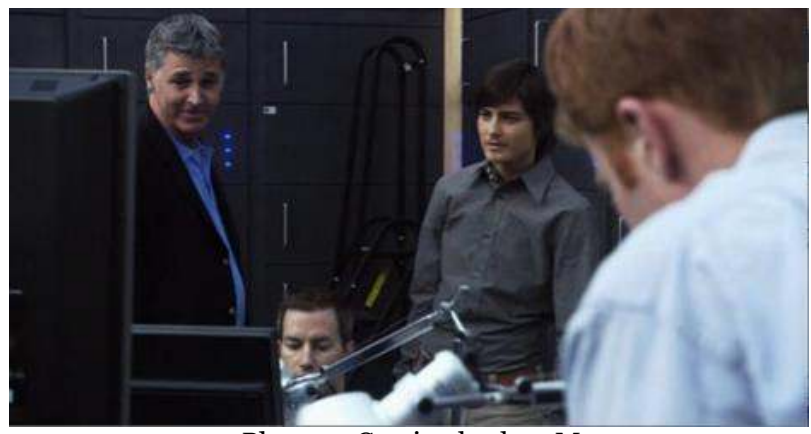

Plate 37: Coming back as Max, 3.10

Max then stands up for a colleague named Megan, who was 
unfairly declined a promotion, and must expose how he was not hired as Moira (4.06), to then be pressured into quitting by the same colleague who did not hire him as a woman (4.11). While in The L Word, the discrimination is entirely attributed to phallocentric sexism, in DTWOF, male and hetero privilege is associated with class privilege, one privilege being presented as sufficient to compensate for the lack of the others.

Sparrow, who is now with impoverished Stuart, cannot help but notice how well they are treated in the same restaurant she patronized with her female lover, who happens to show up and explain that she is treated wonderfully now that she is rich (see Plate 38 ).
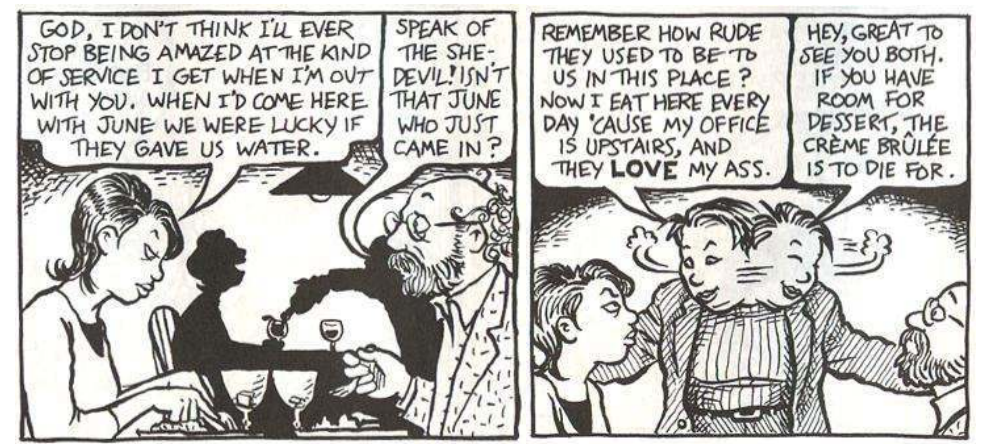

Plate 38: In vol. 10, Dykes and Sundry Other Carbon-Based Life Forms TWOF, 2001, strip 355 .

Although The $L$ Word does tackle a number of political topics, such as same-sex parenting, being out as a professional athlete, gay marriage, medical discrimination, LGBTs in the military and the Don't Ask Don't Tell policy ${ }^{7}$, among other contemporary LGBT rights issues, its political ambitions are much narrower than Bechdel's, so that the show can be interpreted by many as a mainstream, de-politicized offspring of the DTWOF.

Significantly, the heroines are "lesbians," not "dykes." They do not embrace the masculinity that does characterize many female homosexuals, to varying degrees. The uses of the words "lesbian" and "dyke" are good indications of this.

The title of the TV series itself plays on the embarrassment some people have at using the word "lesbian," which the show reclaims and mainstreams, while the theme song implies the "L" word is not just for "Lesbian" but also for "L.A.," "Love," "Lust," and everything that makes

\footnotetext{
7 Don't Ask Don't Tell is a policy established by the Clinton administration according to which gays and lesbians are tolerated within the military as long as their sexual preference is never made public by themselves, or by others.
} 
up these lesbians' lives... It is made clear from the first episode that The $L$ Word heroines are not "dykes" - when Dana calls Shane a dyke, and she does not mean that in a nice way (Plate 39).

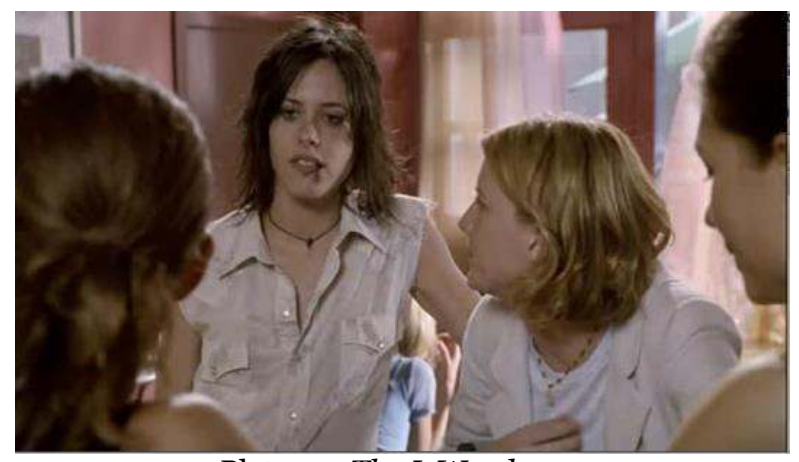

Plate 39: The L Word, 1.01

"Every single thing about the way you're dressed screams dyke."

Tina and Bette need a new donor, Marina says they know enough good men, and as Shane walks in, Dana suggests her as a candidate. She then addresses her to question the way she is dressed, saying she "wouldn't be seen on the street with [her]" as "every single thing about [her] screams dyke." To which Shane perfunctorily apologizes with a "Sorry, man." This common expression to refer to a female friend takes on an ironic tone here since on The $L$ Word, dykes are associated with manliness. Men tend to use the term more easily than women. In season 1, when Tim finds out his girlfriend Jenny is cheating on him with Marina, he rejects Bette's take on the matter:

Tim. What, craving experience? You think so? I think it was you fucking dykes, that's what...

BETTE. Hey, don't curse us all, alright. That's why Tina and I left your dinner party, because we didn't want to be any part of it. (1.07)

Bette's answer is ambiguous, implying that perhaps the word "dyke" is a curse (and though she may well mean only the adjective is offensive, Tim most likely does not). In season 2, Mark uses the word when he says Shane gave him a "dykish haircut", which he likes (2.09). The word is also used by lesbians who are out, and especially by Alice who is played by an out bisexual, Leisha Hailey, and acts as the show's token credible character. She uses the word for the first time when she talks about "dyke drama" to explain why her lesbian-identified boyfriend Lisa is not happy to find her on a date with a straight man (1.10). In Season 1, episode 10, Shane wants to cut Dana's hair and give her a mullet (short at the front and sides, long in the back), but Alice does not think she is ready to be a "bulldyke." Alice does not use the word often 
and when she does, it refers to a negative situation. The only reason Alice can use the term in a derogatory manner, without being offensive, is because she identifies as a dyke herself.

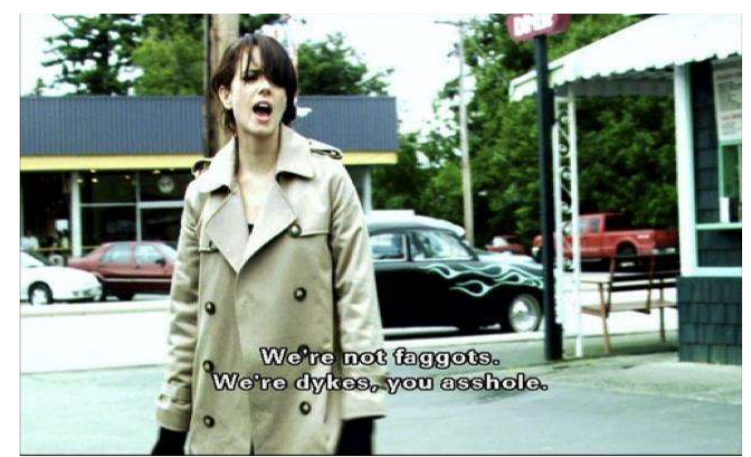

Plate 40: In 3.02, Jenny uses "dyke" as the female equivalent of "faggot" and retorts with the genderless "asshole," against someone who confuses the gender of queers.

The best use of the word on the show is certainly by Jenny in Season 3, episode 2, when she yells at homophobic teenagers who are brutalizing Max and calling both of them "faggots" (see Plate 40) Jenny is not very dykish, to say the least, and although Max is certainly masculine, he does not identify as a woman or as a lesbian. Yet, being part of the LGBT community, they can use the word, especially in selfdefense.

All in all, dykes as characters make few intrusions in the otherwise very "fem" show, and the word is clearly associated with a non-desirable masculinity that lesbians have been, unfairly for all nondykes, associated with. This dykophobia in the lesbian world is nothing new, as Bechdel pointed out in a 1990 strip (see Plate 41).

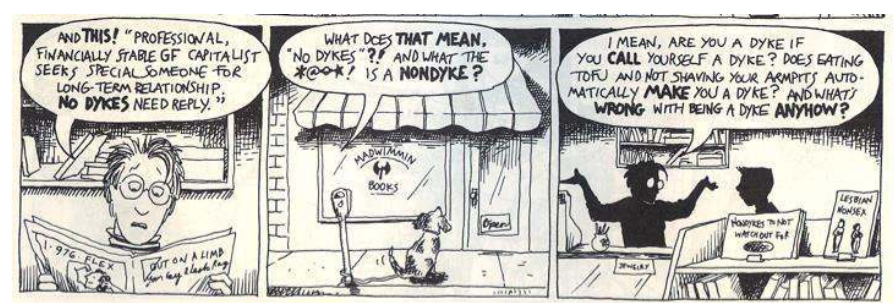

Plate 41: On the bookstore shelf: "Nondykes To Not Watch Out For" and "Lesbian Nonsex" (vol. 4, DTWOF The Sequel, 1990, strip 82).

Self-identifying as lesbians and largely rejecting dyke culture is intrinsically part of The $L$ Word universe, and of a larger feminist 
sensibility that rejects "hairy-legged feminism" in favor of a "stiletto feminism."

Apart from a number of character and plot similarities, The $L$ Word also adopts some of the metafictional approach that pops up from time to time in the DTWOF. Jenny writes short stories about herself and her friends, to eventually write a film about lesbians entitled Lez Girls (in Seasons 5 and 6; see Plate 42), while Bechdel makes fun of herself as an autobiographical artist (see Plate 43).

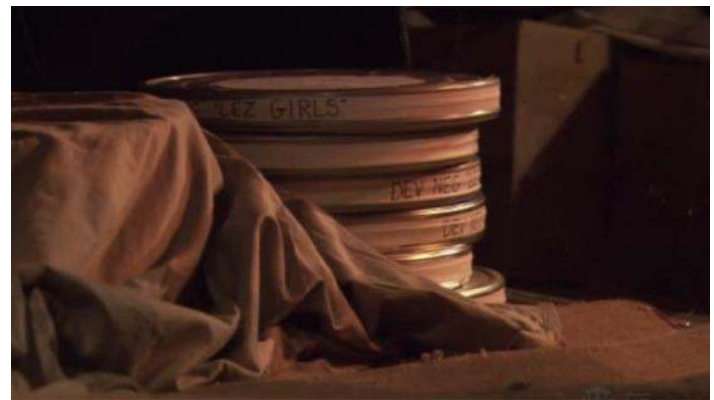

Plate 42: Lez Girls reels, 6.08.

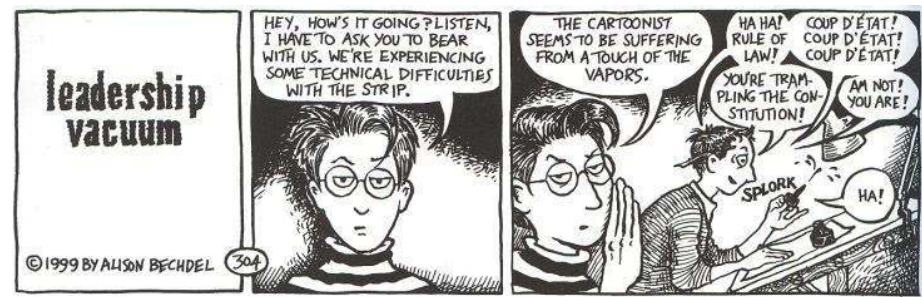

Plate 43: In vol. 9, Post-DTWOF, 1999, strip 304.

But while DTWOF clearly relies on autobiography to attempt to render a universal humanity, The $L$ Word ridicules autobiography through Jenny's character who, in Seasons 5 and 6, does exactly what Alison Bechdel and Ilene Chaiken did: she creates a series based on her group of friends' lives, except that it is clearly disrespectful, and exploitative (see Plate 44), and ultimately destructive. 


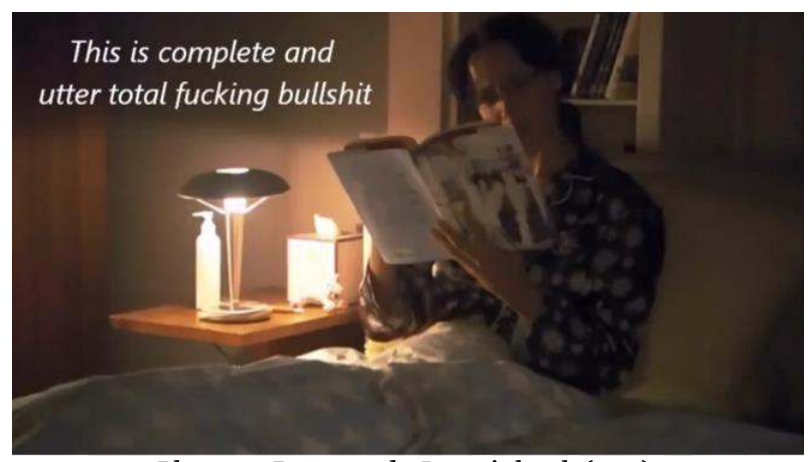

Plate 44: Bette reads Jenny's book (4.11).

I believe this self-destruction impulse mirrors The $L$ Word's major departure from the DTWOF universe: the post-queer need to separate entirely sexual identity from gender non-conformance, which results in denying a huge part of queer culture, not to say dulling it down to its least political elements. Some of The $L$ Word lesbians are said to be fem (Tina, Dana, Marina, Jenny) while others are portrayed as butch (Shane, Bette), but they all look excessively feminine to a non-trained eye, unlike the much more diverse women and transmen in DTWOF. The idea behind this TV-glamour rendition of the lesbian world is that lesbianism is unrelated to gender non-conformance. This is accompanied by a post-racial, "color-blind," strictly cultural understanding of racial diversity (Bette, who easily passes and blends into a white life, as opposed to Clarice, who does not miss an opportunity to teach her son about African American history), and a denial of class differences - not only do all The $L$ Word lesbians seem equally rich, in spite of very different professional situations, but they all eventually become very successful in their respective trades, whether in publishing, hair-styling, or film production, as opposed to the DTWOF, which present a much broader spectrum of financial situations and professional success. This very different take on race, class, gender and sexuality largely explains why, in comparison with The $L$ Word lesbian friends, Bechdel's much more political dykes deliver a political message that is much broader, all-encompassing than the LGBT-focused The $L$ Word.

\section{The author}

Anne Crémieux is Associate Professor in American Studies at the University of Paris West Nanterre. She has published Black American Filmmakers and the Hollywood Dream (Paris, L'Harmattan, 2004), edited CinémAction 143 
"Minorities in American Cinema (Paris, Le Cerf, 2012) and co-edited Understanding Blackness Through Performance (New York, Palgrave Macmillan, 2013). 